\title{
What Underpins the Trophic Networks of the Plankton in Shallow Oxbow Lakes?
}

\author{
J. Kosiba ${ }^{1}$ • E. Wilk-Woźniak ${ }^{1}$-W. Krztoń ${ }^{1} \cdot$ M. Strzesak ${ }^{1} \cdot$ A. Pociecha $^{1}$. \\ E. Walusiak ${ }^{1} \cdot$ K. Pudaś $^{2} \cdot$ E. Szarek-Gwiazda ${ }^{1}$
}

Received: 10 March 2016 / Accepted: 8 August 2016 / Published online: 20 August 2016

(C) The Author(s) 2016. This article is published with open access at Springerlink.com

\begin{abstract}
The aim of this study was to determine the relationships in the microbial trophic network underpinning them about communities of plankton ciliates in shallow oxbow lakes of the Vistula River in southern Poland (Jeziorzany 1, Jeziorzany 2, Piekary, Tyniec). The plankton components (phytoplankton, ciliates, zooplankton) were grouped by dietary preference. The studied oxbows differed in physicochemical parameters and in phytoplankton. Cyanobacteria dominated in the total biomass of phytoplankton in the Tyniec oxbow, big green algae $(>30 \mu \mathrm{m})$ in Piekary and Jeziorzany 1 , and euglenoids in Jeziorzany 2 oxbow. The dominance pattern of ciliates and zooplankton were similar in all oxbows. Algivorous ciliates were the main dominant ciliates, and among zooplankton the dominant ones were herbivores that feed on small algae $(<30 \mu \mathrm{m})$. The oxbows differed significantly in total phytoplankton biomass, cyanobacteria biomass, euglenoid biomass, small green algae $(<30 \mu \mathrm{m})$ biomass, total biomass of zooplankton, biomass of zooplankton feeding on bacteria + algae, and biomass of zooplankton feeding on big algae $(>30 \mu \mathrm{m})$. There was no significant differences in ciliate biomass between oxbows. In redundancy analyses, the variability at the trophic groups of plankton was described by explanatory variables in $42.3 \%$, and positive relationships were found: e.g., between omnivorous zooplankton biomass, the biomass of ciliates feeding on bacteria + algae, and $\mathrm{NH}_{4}$
\end{abstract}

E. Wilk-Woźniak

wilk@iop.krakow.pl

1 Institute of Nature Conservation, Department of Freshwater Biology, Polish Academy of Sciences, al. A. Mickiewicza 33, 31-120 Krakow, Poland

2 Central Laboratory, Municipal Water and Sewage Company, Lindego 9, 30-148 Krakow, Poland level; between euglenoid biomass and dinoflagellate biomass; and between cyanobacteria biomass and bacterivorous ciliate biomass. Spearman correlation analysis revealed several relationships between different groups of plankton. In general, phytoplankton group shows more connection among themselves and with different zooplankton groups, e.g., phytoplankton biomass with herbivorous zooplankton biomass $(-0.33)$; and cyanobacteria biomass with dinoflagellate biomass (0.65). Ciliates showed more connections among their trophic groups (e.g., algivorous ciliate biomass with omnivorous ciliate biomass, 0.78 ) and with zooplankton trophic groups (e.g., biomass of algivorous + bacterivorous ciliates with biomass of predator zooplankton, -0.36 ). Simple correlations analysis revealed the trophic food web network connectivity among plankton organisms, indicating the flow of organic matter from phytoplankton to zooplankton and from ciliates to zooplankton. Our study sheds light on the trophic relations among plankton ciliates, which are neglected in research but often form a large percentage of zooplankton biomass. In the studied oxbows, ciliate forms $6.7 \%$ of total zooplankton biomass in Jeziorzany 1 and up to $44.5 \%$ of it in the Piekary oxbow.

Keywords Trophic networks · Ciliates · Zooplankton · Phytoplankton · Oxbow lakes

\section{Introduction}

Microorganisms are basic components functioning in all water ecosystems playing role in maintenance of nutrient cycles. Our understanding of aquatic microbial ecology, particularly the interactions in those trophic networks, is still far from sufficient. To study them, network analyses employ quantitative food web models which describe the energy flow of an 
ecosystem and provides information about how the nature of the ecosystem has changed over time.

This type of research is especially needed for oxbow lakes, one of the most endangered landscape elements, which are disappearing due to river regulation, dam building and alteration of rivers and floodplains [1]. Oxbows are important habitats and refuges for microorganisms [2,3]; they increase biodiversity and play an important role in maintaining gene pools [4].

Studies of the relationship among water organisms have a long history (e.g., [5-9]) and often focus on single relationship (in laboratory experiments; e.g., [10]) or simple trophic relationship (Fig. 1). For the management and maintenance of healthy water ecosystem, the interaction between the smallest components of trophic network in freshwaters must be known. Oxbow lakes tend to be naturally eutrophic. According to some authors, production in such ecosystems depends on "new nutrients," and the classical pelagic food chain plays a more important role [11] than recycling of nutrients via microbial loops; the latter is more important in oligotrophic ecosystems [12], though some studies have confirmed the

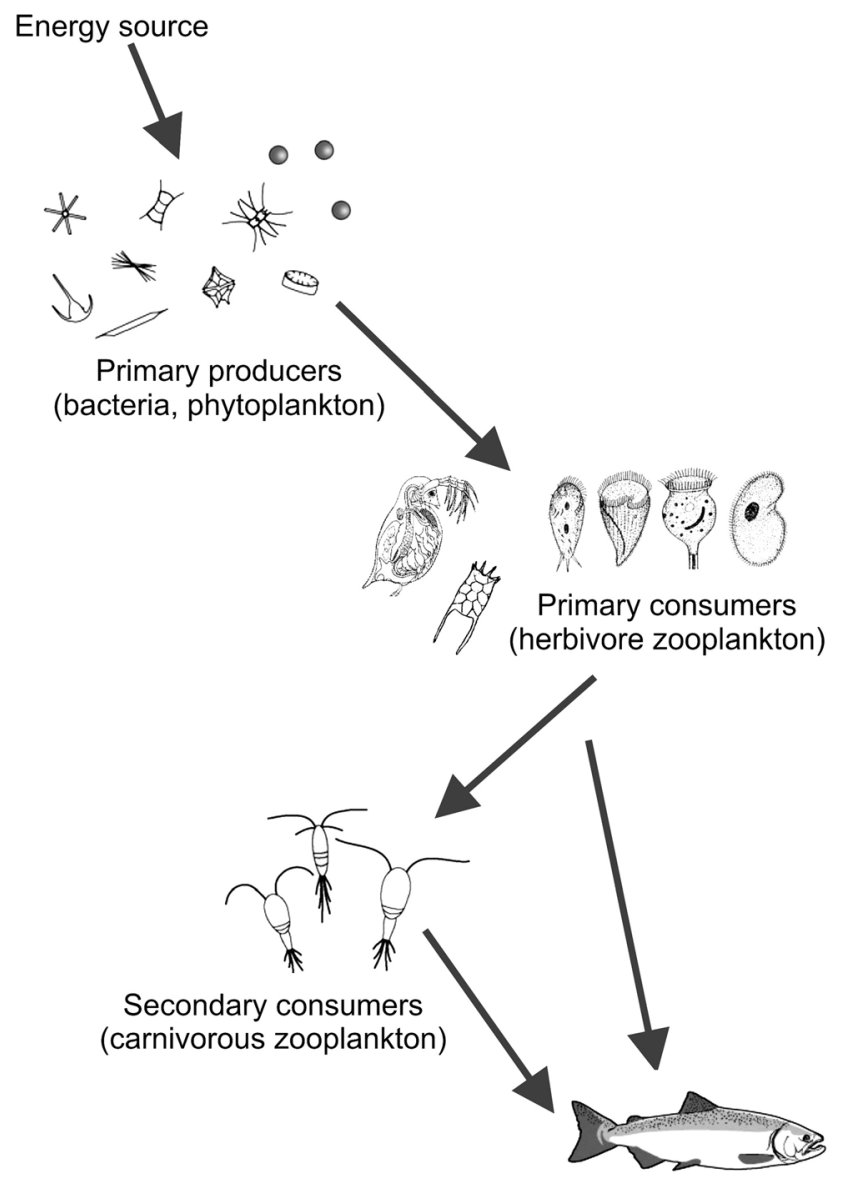

Higher level consumers (fish)

Fig. 1 Scheme of trophic relationships in water ecosystems importance of microbial loops in eutrophic ecosystems as well $[9,13]$.

Thirty years ago, the PEG model [14] explained the role of abiotic and biotic factors as significant drivers of phytoplankton and zooplankton development in lakes, but today still we do not have a full grasp of the processes occurring in oxbow ecosystems. Because they are hydrologically variable, as lotic, lentic and semilotic types [15], the interactions among the components of their food webs are dependent on hydrological pulses [16]. A model of microbiological food web connections during different hydrological phases was recently proposed [17], but hydrological factors are not the only one regulating plankton relationships. Interbiotic relations between different components of plankton are also important.

The aim of this study was to determine the relationships in the trophic network of plankton components in shallow oxbow lakes, in order to improve our understanding of how carbon and energy is transferred among the microbial organisms inhabiting them.

\section{Materials and Methods}

Samples were collected from four oxbow lakes of Poland's largest river, the Vistula: Jeziorzany 1 (J1), Jeziorzany 2 (J2), Piekary $(\mathrm{P})$ and Tyniec $(\mathrm{T})$. These lakes are located in southern Poland in or near the city of Krakow, and are small, covering ca. 1.5-5.7 ha (Table 1).

Samples were collected from the deepest part of each reservoir from May to October 2014, each month prior to cyanobacterial bloom formation and every week during bloom growth. We collected 108 samples for biological analyses (36 phytoplankton samples, 36 ciliate samples, 36 zooplankton samples). For physicochemical analyses, we collected 72 samples: 36 samples at $1 \mathrm{~m}$ depth and 36 samples near the lake bottom but finally used only the samples from $1 \mathrm{~m}$ depth for those tests. Water temperature, oxygen saturation, $\mathrm{pH}$, conductivity and chlorophyll a concentration were measured in situ with a YSI 6600 V2 multiparameter sonde. Samples for analysis of anions $\left(\mathrm{HCO}_{3}^{-}, \mathrm{SO}_{4}{ }^{2-}, \mathrm{Cl}^{-}, \mathrm{NO}_{3}{ }^{-}, \mathrm{PO}_{4}{ }^{3-}\right)$ and cations $\left(\mathrm{Ca}^{2+}, \mathrm{Mg}^{2+}, \mathrm{Na}^{+}, \mathrm{K}^{+}, \mathrm{NH}_{4}^{+}\right)$were immediately transported to the laboratory. Ion concentrations were measured with a Dionex Ion Chromatograph (DIONEX, IC25 Ion Chromatograph; ICS-1000, Sunnyvale, CA, USA) in the laboratory of the Institute of Nature Conservation, Polish Academy of Sciences.

Samples for biological parameters were taken from $1 \mathrm{~m}$ depth using a $5 \mathrm{~L}$ Ruttner sampler and were concentrated from $10 \mathrm{~L}$ with a plankton net (mesh size $10 \mu \mathrm{m}$ for phytoplankton and ciliates, and $50 \mu \mathrm{m}$ for the rest of zooplankton). 
Table 1 Geographical coordinates and chosen parameters of the studied oxbows

\begin{tabular}{|c|c|c|c|c|c|}
\hline \multirow[t]{2}{*}{ Parameter } & & \multicolumn{4}{|l|}{ Oxbows } \\
\hline & & $\mathrm{J} 1$ & $\mathrm{~J} 2$ & $\mathrm{P}$ & $\mathrm{T}$ \\
\hline \multicolumn{2}{|l|}{ Geographical coordinates } & $\begin{array}{l}49^{\circ} 59^{\prime} 46.0^{\prime \prime} \mathrm{N} \\
19^{\circ} 46^{\prime} 52.5^{\prime \prime} \mathrm{E}\end{array}$ & $\begin{array}{l}49^{\circ} 59^{\prime} 43.7^{\prime \prime} \mathrm{N} \\
19^{\circ} 47^{\prime} 10.6^{\prime \prime} \mathrm{E}\end{array}$ & $\begin{array}{l}50^{\circ} 00^{\prime} 50.1^{\prime \prime} \mathrm{N} \\
19^{\circ} 47^{\prime} 35.7^{\prime \prime} \mathrm{E}\end{array}$ & $\begin{array}{l}50^{\circ} 01^{\prime} 47.0^{\prime \prime} \mathrm{N} \\
19^{\circ} 49^{\prime} 39.8^{\prime \prime} \mathrm{E}\end{array}$ \\
\hline \multicolumn{2}{|l|}{ Area [ha] } & 2.21 & 2.19 & 1.56 & 5.75 \\
\hline \multicolumn{2}{|l|}{ Max. depth [m] } & 2.40 & 5.50 & 4.00 & 3.00 \\
\hline \multirow[t]{2}{*}{ Temperature $\left[{ }^{\circ} \mathrm{C}\right]$} & Range (mean) & $12.7-23.3(18.5)$ & $14.7-25.0(20.7)$ & $8.7-24.3(17.3)$ & $9.3-24.7(17.9)$ \\
\hline & $\mathrm{CV}$ & 23 & 23 & 27 & 26 \\
\hline \multirow[t]{2}{*}{$\mathrm{pH}$} & Range & $7.1-7.6$ & $7.2-8.1$ & $6.4-8.3$ & $6.8-8.3$ \\
\hline & $\mathrm{CV}$ & 3 & 4 & 7 & 6 \\
\hline \multirow[t]{2}{*}{ Oxygen saturation [\%] } & Range (mean) & $27.4-94.6(60.9)$ & $75.7-115.2(95.2)$ & $53.1-100.8(53.1)$ & $41.0-169.6(88.3)$ \\
\hline & $\mathrm{CV}$ & 40 & 14 & 24 & 43 \\
\hline \multirow[t]{2}{*}{ Conductivity $\left[\mu \mathrm{S} \mathrm{cm}^{-1}\right]$} & Range (mean) & $748-773(802.0)$ & 682-697 (690.8) & 481-958 (653.0) & $1268-1360(1297.5)$ \\
\hline & $\mathrm{CV}$ & 1 & 1 & 19 & 2 \\
\hline \multirow[t]{2}{*}{$\mathrm{HCO}_{3}^{-}[\mathrm{mg} / \mathrm{L}]$} & Range (mean) & $229.8-306.9(281.0)$ & $202.9-280.2(257.6)$ & $196.4-265.1(242.2)$ & $224.9-317.0(283.8)$ \\
\hline & $\mathrm{CV}$ & 11 & 12 & 8 & 11 \\
\hline \multirow[t]{2}{*}{$\mathrm{SO}_{4}{ }^{2-}[\mathrm{mg} / \mathrm{L}]$} & Range (Mean) & $43.3-65.9(52.9)$ & $44.6-64.2(51.8)$ & $21.2-78.1(36.7)$ & 75.9-100.1 (84.7) \\
\hline & $\mathrm{CV}$ & 14 & 14 & 40 & 8 \\
\hline \multirow[t]{2}{*}{$\mathrm{NO}_{3}^{-}[\mathrm{mg} / \mathrm{L}]$} & Range (mean) & $0.23-0.95(0.58)$ & nd-1.15 (0.47) & $0.18-1.03(0.39)$ & nd-1.06 (0.53) \\
\hline & $\mathrm{CV}$ & 53 & 110 & 62 & 46 \\
\hline \multirow[t]{2}{*}{$\mathrm{NH}_{4}^{+}[\mathrm{mg} / \mathrm{L}]$} & Range (mean) & $0.005-0.320(0.140)$ & $0.009-0.219(0.071)$ & $0.025-0.557(0.183)$ & $0.029-0.780(0.220)$ \\
\hline & $\mathrm{CV}$ & 106 & 111 & 88 & 101 \\
\hline \multirow[t]{2}{*}{$\mathrm{PO}_{4}{ }^{3-}[\mathrm{mg} / \mathrm{L}]$} & Range (mean) & nd-0.030 (0.008) & nd-0.068 (0.026) & nd-0.190 (0.060) & nd-0.490 (0.150) \\
\hline & $\mathrm{CV}$ & 169 & 122 & 92 & 108 \\
\hline \multirow[t]{2}{*}{$\mathrm{Mg}^{2+}[\mathrm{mg} / \mathrm{L}]$} & Range (mean) & $4.60-8.11(7.04)$ & $4.30-7.94(6.91)$ & $6.50-16.75$ (13.06) & $11.90-21.83(18.94)$ \\
\hline & $\mathrm{CV}$ & 19 & 21 & 20 & 13 \\
\hline \multirow[t]{2}{*}{ Chl $a[\mu \mathrm{g} / \mathrm{L}]$} & Range (mean) & $3.1-39.7(21.2)$ & $6.2-24.2(13.2)$ & $3.7-94.4(32.3)$ & $11.0-140.0(37.3)$ \\
\hline & $\mathrm{CV}$ & 72 & 53 & 89 & 89 \\
\hline
\end{tabular}

n.d. undetectable level, $C V$ coefficient of variation

Since all the oxbows were relatively shallow and polymictic, no epilimnion, metalimnion, or hypolimnion were present. We took biological samples from $1 \mathrm{~m}$ depth because preliminary studies in previous years (unpubl. data) had shown that the diversity and biomass of plankton organisms, and especially phytoplankton, were highest at that depth, a finding supported by studies of ciliates and zooplankton: ciliates that are mixotrophic or consume algae prefer the upper levels of water $[18,19]$; during the summer, the hypolimnetic refuge is not available to migratory zooplankton due to anoxic conditions [20].

Samples for quantitative analyses were immediately fixed with Lugol's solution for algae and ciliates, and with $4 \%$ formaldehyde for the rest of the zooplankton. Samples for phytoplankton, ciliates, and zooplankton (rotifers, cladocerans, copepods) were taken separately. Additional fresh samples, not fixed but concentrated as described above, were taken for species composition analysis of live material. Phytoplankton species were identified and counted in a modified chamber ( $0.4 \mathrm{~mm}$ high, $22 \mathrm{~mm}$ diameter). Phytoplankton biomass was calculated from the cell numbers and specific volumes [21].

Ciliates were determined taxonomically from living material in a $1-\mathrm{mL}$ chamber with a glass cover, according to Foissner and Berger [22, 23]. The total biomass of ciliates $(\mathrm{mg} / \mathrm{L})$ was calculated according to Jerome et al. [24], Menden-Deuer and Lessard [25], Wiąckowski et al. [26] and Putt and Stoecker [27].

Zooplankton samples were analyzed in a $0.5-\mathrm{mL}$ chamber. Average of five counts were calculated. The species were identified with keys [28-31]. Dry weight was calculated using a regression equation for body length and weight for each species [32-36]. Because phytoplankton and ciliates were calculated as fresh biomass, zooplankton dry mass was recalculated according to the index proposed by Bottrell et al. [34].

The above analyses employed a Nikon H550L light microscope at $40-1000 \times$. 
To describe the network structure, microorganisms were divided by trophic group: primary producers (phytoplankton), protozoan consumers (ciliates), and metazoan consumers (zooplankton - rotifers, cladocerans, copepods). Producers were subdivided into size and trophic classes: cyanobacteria (only large colonies or trichomes were present in the collected samples), big diatoms ( $>30 \mu \mathrm{m})$, small diatoms $(<30 \mu \mathrm{m})$, big green algae $(>30 \mu \mathrm{m})$, small green algae $(<30 \mu \mathrm{m})$, and mixotrophic algae. Mixotrophic algae were grouped as follows: cryptophytes (sparse phagotrophic species), golden brown algae (equal use of phagotrophy and phototrophy; e.g., Dinobryon [37]), dinophytes, and euglenoids. Ciliates were grouped as follows: species that feed on algae, bacterivorous species, algivorous and bacterivorous species, and omnivorous species [22, 23]. Zooplankton group was divided into species that feed on the seston and bacteria, species that feed on algae $>30 \mu \mathrm{m}$, species that feed on algae $<30 \mu \mathrm{m}$, predators, and omnivorous species [38].

The basic statistics used for data analysis were range (minimum-maximum), average, standard deviation (SD) and coefficient of variation (CV). The Kruskal-Wallis test was used to determine the significance of differences in biomass between the different plankton components of oxbows. Spearman correlations were used to build a model to explain the relationships between plankton components, and redundancy analysis (RDA) was used to build a model to explain the relationships between plankton components and physicochemical parameters. Statistica 10.0 and CANOCO 5 for Windows were used for these statistical analyses. The data were log-transformed. The manual forward selection procedure was run using the Monte Carlo permutation test. Variables having a conditional effect that was significant at $p<0.05$ were included.

\section{Results}

\section{Physicochemical Factors}

All the oxbows are in the same geographical zone and are exposed to the same climate, but showed differences in physicochemical parameters (Table 1).

The shallowest oxbow was J1 (2.4 m) and the deepest was $\mathrm{J} 2(5.5 \mathrm{~m})$. Table 1 represents the parameters bearing any relation to plankton components as assessed by RDA. Variation $(\mathrm{CV})$ of water temperature in $\mathrm{J} 1$ and $\mathrm{J} 2$ was similar, and was higher in $\mathrm{P}$ oxbow and $\mathrm{T}$ oxbow. Water $\mathrm{pH}$ showed a similar tendency. Variation of oxygen saturation was highest in $\mathrm{J} 1$ and $\mathrm{T}$. Mean conductivity was highest in the water of $\mathrm{T}$, and variation of conductivity was highest for $\mathrm{P}$. Mean $\mathrm{NH}_{4}{ }^{+}$ and $\mathrm{PO}_{4}{ }^{3-}$ concentrations were highest in $\mathrm{T}$, and $\mathrm{NO}_{3}{ }^{-}$was highest in J1. Other parameters also differed oxbows from each other.

\section{Phytoplankton}

The phytoplankton consisted of cyanobacteria, golden brown algae, cryptomonads, dinoflagellates, euglenoids, diatoms, and green algae. Golden brown algae and cryptomonads were found only occasionally in single samples. The mean total biomass of phytoplankton was highest in T and lowest in J2. Variation of total phytoplankton biomass was highest in $\mathrm{P}$ (Table 2).

The pattern of dominance in the total biomass of phytoplankton was somewhat similar for $\mathrm{J} 1$ and $\mathrm{J} 2$, however differed between the oxbows (Fig. 2):

J1: big green algae $>$ euglenoids $>$ dinoflagellates $>$ small green algae.

J2: euglenoids $=$ big green algae $>$ cyanobacteria .

P: big green algae $>$ euglenoids $>$ cyanobacteria $>$ dinoflagellates.

T: cyanobacteria $>$ euglenoids $>$ dinoflagellates.

\section{Ciliates}

The plankton ciliates consisted of the following groups: (1) algivorous ciliates (Oligotrichida: Codonella cratera, Tintinidium sp.; Prostomatida: Coleps spetai); (2) bacterivorous ciliates (Peritrichia: Epistylis sp., Vorticella sp.; Hypotrichia: Aspidisca sp.); (3) mixed type of feeding ciliates that feed on algae and bacteria (Oligotrichida: Strobilidium sp.; Peritrichia: Vorticella campanula); and (4) omnivorous species (Hymenostomata: Cinetochilum margaritaceum, Paramecium bursaria; Hypotrichia: Euplotes patella; Prostomatida: Coleps hirtus: Heterotrichida: Stentor sp.). Mean total biomass of plankton ciliates and variation of total biomass were highest for $\mathrm{P}$ and lowest for J1 (Table 2).

The pattern of dominance in the total biomass of ciliates was similar for all oxbows (Fig. 3):

J1: algivorous ciliates $>$ omnivorous ciliates $>$ bacterivorous ciliates $>$ algivorous and bacterivorous ciliates

$\mathrm{J} 2$ : algivorous ciliates $>$ algivorous and bacterivorous ciliates $>$ omnivorous ciliates $>$ bacterivorous ciliates

P: algivorous ciliates $>$ omnivorous ciliates $>$ bacterivorous ciliates

T: algivorous ciliates $>$ omnivorous ciliates $>$ bacterivorous ciliates

For all oxbows taken together, algivorous ciliates were dominant, followed by omnivorous ciliates. Bacterivorous and bacterio-algivorous ciliates had lower shares of total ciliate biomass. 
Table 2 Biomass ( $\mathrm{mg} / \mathrm{L})$ of phytoplankton, plankton ciliates and zooplankton in oxbows - basic statistics

\begin{tabular}{|c|c|c|c|c|c|c|c|c|c|c|c|c|}
\hline \multirow[b]{2}{*}{ Statistic } & \multicolumn{3}{|l|}{$\mathrm{J} 1$} & \multicolumn{3}{|l|}{$\mathrm{J} 2$} & \multicolumn{3}{|l|}{$\mathrm{P}$} & \multicolumn{3}{|l|}{$\mathrm{T}$} \\
\hline & Phyto & Ciliates & Zoo & Phyto & Ciliates & Zoo & Phyto & Ciliates & Zoo & Phyto & Ciliates & Zoo \\
\hline Min-max & $4.8-28.5$ & $0.07-1.1$ & $1.9-9.3$ & $1.8-12.4$ & $0.1-2.6$ & $0.5-6.3$ & $1.0-30.6$ & $0.1-26.7$ & $4.1-19.1$ & $3.9-163.3$ & $0.07-12.0$ & $4.0-12.4$ \\
\hline Average & 14.8 & 0.5 & 6.7 & 6.5 & 1.0 & 4.0 & 11.9 & 8.0 & 9.9 & 65 & 3.7 & 8.1 \\
\hline $\mathrm{SD}$ & 9.9 & 0.4 & 2.6 & 4.4 & 0.9 & 1.9 & 10.8 & 9.5 & 4.5 & 44. 5 & 3.9 & 2.8 \\
\hline $\mathrm{CV}(\%)$ & 67 & 75 & 39 & 68 & 90 & 48 & 90 & 119 & 46 & 69 & 108 & 34 \\
\hline
\end{tabular}

$S D$ standard deviation, $C V$ coefficient of variation

\section{Zooplankton}

Zooplankton consisted of the following trophic groups: (1) seston-feeding and bacterivorous animals (rotifers: Brachionus angularis, B. diversicornis, B. urceolaris, Filinia longiseta, Keratella cochlaris, K. tecta, Polyarthra major, P. remata, P. vulgaris, Pompholyx sulcata; copepods: nauplii), $2)$ herbivorous animals that feed on small algae $(<30 \mu \mathrm{m})$ (rotifers: Brachionus calyciflorus, Kellicotia longispina, Keratella quadrata, Trichocerca similis; cladocerans: Bosmina longirostris, Chydorus sphaericus, Diaphanosoma brachyurum, Eubosmina coregoni, E. gibera, E. longispina, Moina micrura; copepods: Acanthocyclops venustus, Cyclops vicinus, Eurytemora affinis, copepodites); (3) herbivorous animals that feed on algae larger than $30 \mu \mathrm{m}$ (cladocerans: Daphnia ambigua, D. cucullata, D. longispina, copepods: Eudiaptomus gracilis); (4) predators (cladocerans: Leptodora kindtii; copepods: Cyclops abyssorum, C. strennus, Thermocyclops crassus); and (5) omnivorous species (rotifers: Asplanchna priodonta, Gastropus minor, Trichocerca capucina; copepods: Mesocyclops leuckartii, Metacyclops gracilis).
Fig. 2 Percentage shares of different phytoplankton groups in total phytoplankton biomass in the four studied oxbow lakes. Abbreviations: J1: Din dinoflagellates, Eug euglenoids, $B G a$ big green algae, $S G a$ small green algae, Others cyanobacteria, golden brown algae, diatoms. J2: Din dinoflagellates, Eug euglenoids, $B G a$ big green algae, $S G a$ small green algae, $C y$ cyanobacteria, Others golden brown algae, diatoms. $P$ : Din dinoflagellates, Eug euglenoids, $B G a$ big green algae, $C y$ cyanobacteria, Others small green algae, golden brown algae, diatoms, cryptomonads. $T$ : Cy cyanobacteria, Din dinoflagellates, Eug euglenoids, Others green algae, diatoms, cryptomonads
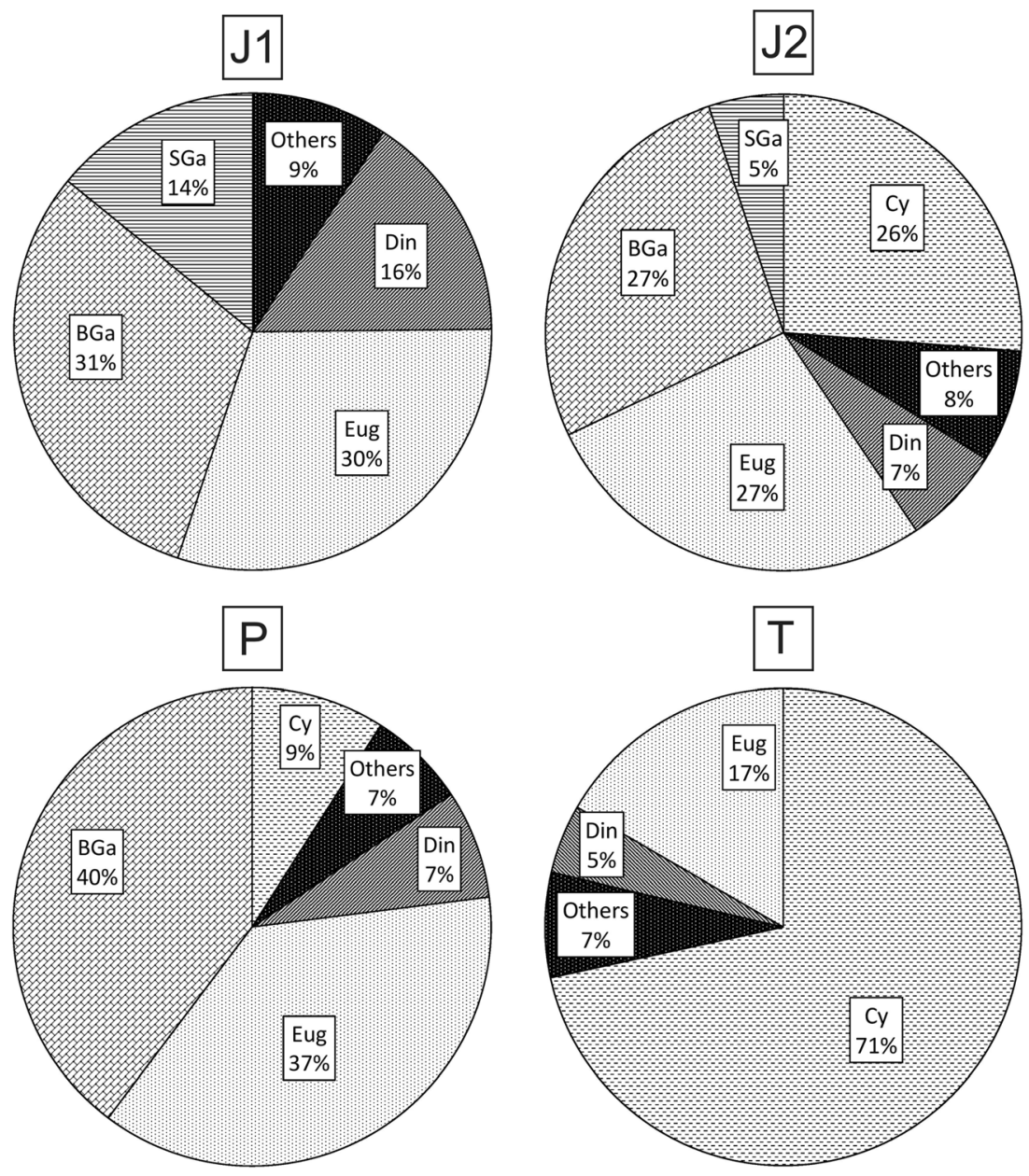
Fig. 3 Percentage shares of different ciliate groups in total ciliate biomass in the four studied oxbow lakes. Abbreviations: $J 1$ :

$\mathrm{Cal}$ algivorous ciliates, $\mathrm{Cbal}$ algivorous and bacterivorous ciliates, $C o$ omnivorous ciliates, $\mathrm{Cb}$ bacterivorous ciliates, $\mathrm{J} 2: \mathrm{Cal}$ algivorous ciliates, $\mathrm{Cbal}$ algivorous and bacterivorous ciliates, Co omnivorous ciliates, $\mathrm{Cb}$ bacterivorous ciliates, $\mathrm{P}: \mathrm{Cal}$ algivorous ciliates, $\mathrm{Co}$ omnivorous ciliates, $\mathrm{Cb}$ bacterivorous ciliates. $\mathrm{T}$ : $\mathrm{Cal}$ algivorous ciliates, $C o$ omnivorous ciliates, $\mathrm{Cb}$ bacterivorous ciliates
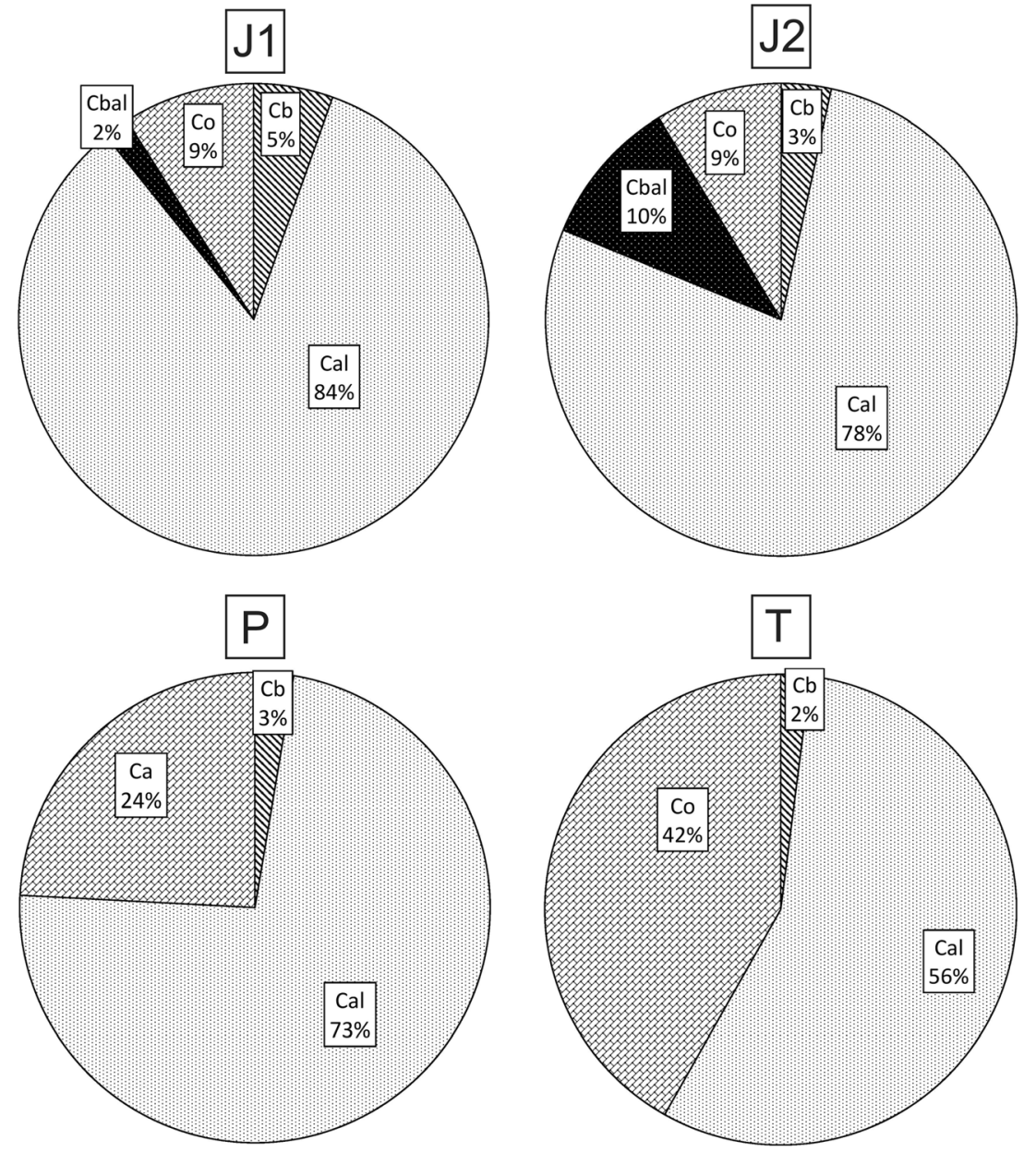

Variation of total zooplankton biomass was highest for J2 and $\mathrm{P}$, and lowest for $\mathrm{T}$ (Table 2).

Herbivores that feed on algae smaller than $30 \mu \mathrm{m}$ were dominant in all oxbows. Three oxbows (J1, J2, P) showed a similar pattern of dominant species; $\mathrm{T}$ differed from the others (Fig. 4):

J1: herbivores that feed on small algae $(<30 \mu \mathrm{m})>$ seston-feeding and bacterivorous animals $>$ predators $>$ omnivores.

J2: herbivorous animals that feed on small algae $>$ seston-feeding and bacterivorous animals $>$ herbivorous animals that feed on big algae $>$ predators $>$ omnivores.

P: herbivorous animals that feed on small algae $>$ seston-feeding and bacterivorous animals $>$ omnivores $>$ predators $>$ herbivorous animals that feed on big algae.

T: herbivorous animals that feed on small algae $>$ predators $>$ herbivorous animals that feed on big algae $>$ omnivores $>$ seston-feeding and bacterivorous animals.

\section{Total Plankton}

There were significant differences in total phytoplankton biomass between $\mathrm{J} 2$ and $\mathrm{T}$ and between $\mathrm{P}$ and $\mathrm{T}$ (Table 3), in cyanobacterial biomass between $\mathrm{J} 1$ and $\mathrm{T}$, in euglenoid biomass between $\mathrm{J} 2$ and $\mathrm{T}$, in the biomass of small green algae between $\mathrm{J} 1$ and $\mathrm{P}$ and between $\mathrm{P}$ and $\mathrm{T}$, in total zooplankton biomass between $\mathrm{J} 2$ and $\mathrm{T}$, in the biomass of zooplankton that feeds on the seston and bacteria between $\mathrm{J} 1$ and $\mathrm{T}$ and between $\mathrm{P}$ and $\mathrm{T}$, and in the biomass of zooplankton that feeds on big algae between $\mathrm{J} 1$ and $\mathrm{T}$. Neither total ciliate biomass nor the biomass of any ciliate group differed between oxbows.

\section{Statistical Analysis}

Spearman correlation revealed several relationships between different groups of plankton (Table 4). RDA analysis showed relationship between different groups and abiotic parameters. The explanatory variables described 
Fig. 4 Percentage shares of different zooplankton groups in total zooplankton biomass in the four studied oxbow lakes. Abbreviations: J1: Zsb seston and bacterivorous animals, $Z h<30$ herbivorous animals that feed on small algae, $Z p$ predators, $Z o$ omnivorous zooplankton. $J 2: Z s b$ seston and bacterivorous animals, $Z h<30$ herbivorous animals that feed on small algae, $Z h>30$ herbivorous animals that feed on big algae, $Z p$ predators, $Z o$ omnivorous zooplankton. $P: Z s b$ seston and bacterivorous animals, $Z h<30$ herbivorous animals that feed on small algae, $Z h>30$ herbivorous animals that feed on big algae, $Z p$ predators, $Z o$ omnivorous zooplankton. $T: Z s b$ seston and bacterivorous animals, $Z h<30$ herbivorous animals that feed on small algae, $Z h>30$ herbivorous animals that feed on big algae, $Z p$ predators, $Z o$ omnivorous zooplankto
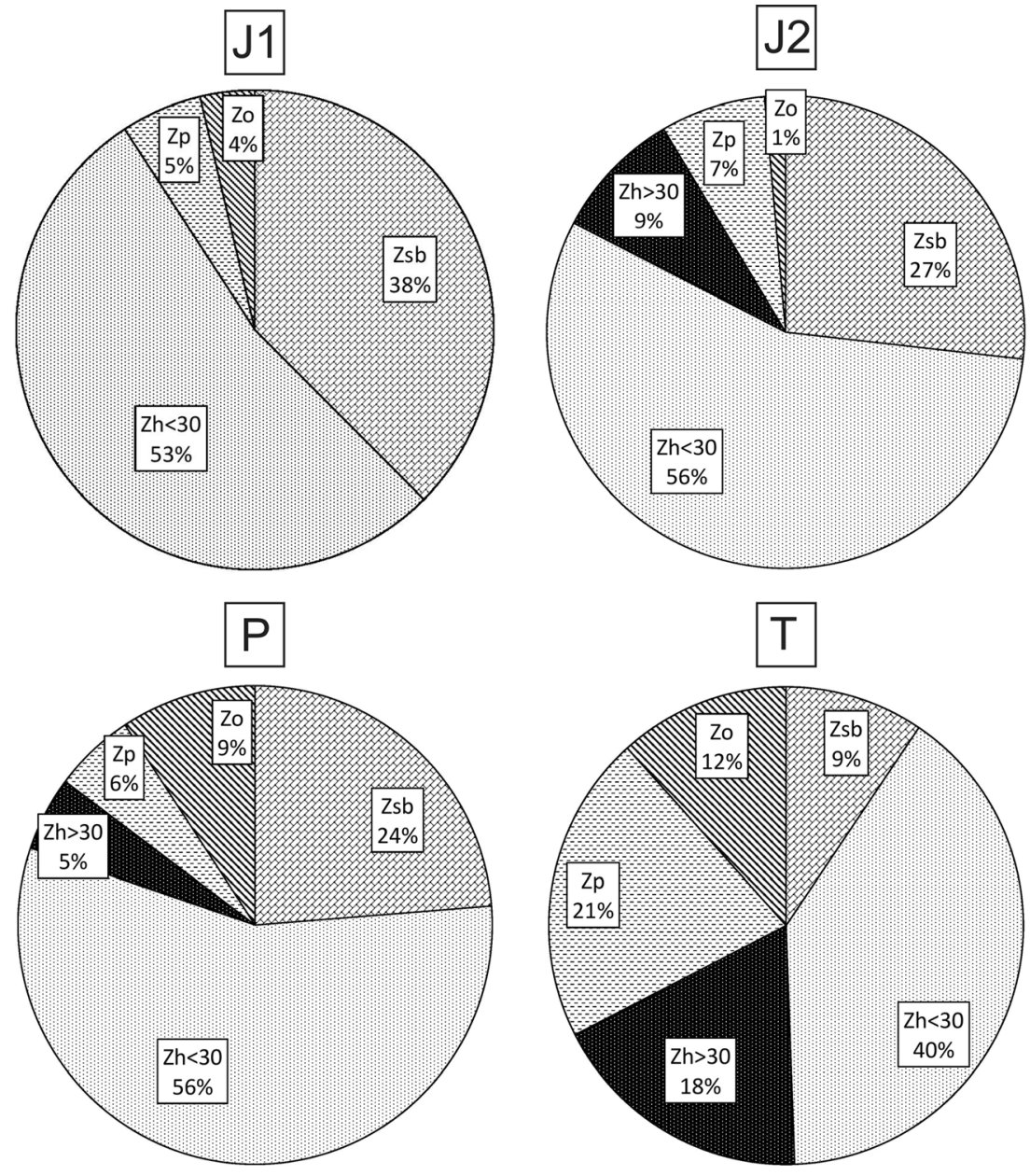

$42.3 \%$ variability at plankton trophic groups in oxbow lakes (Fig. 5). We noted the following groups of positive relationship: $(a)$ the biomass of big green algae, the biomass of herbivorous zooplankton that feeds on small algae $(<30 \mu \mathrm{m})$, the biomass of omnivorous zooplankton, the biomass of ciliates that feed on bacteria and algae, and the concentration of $\mathrm{NH}_{4}{ }^{+} ;(b)$ the biomass of small green algae, the biomass of zooplankton that
Table 3 Statistically significant differences between various components of plankton and between oxbows (KruskalWallis test; $z$ statistic value; $p$ level of significance)

\begin{tabular}{llrr}
\hline Biomass & Oxbow lake & $z$ & $p$ \\
\hline Total biomass of phytoplankton & Jeziorzany 2 - Tyniec & 3.097 & 0.012 \\
H $(3, N=36)=13.56$ & Piekary - Tyniec & 2.979 & 0.017 \\
Biomass of cyanobacteria & Jeziorzany 1- Tyniec & 3.336 & 0.005 \\
H $(3, N=36)=13.14$ & & & \\
Biomass of euglenoids & Jeziorzany2 - Tyniec & 2.721 & 0.039 \\
H $(3, N=36)=8.77$ & & & \\
Biomass of small green algae & Jeziorzany 1 - Piekary & 3.970 & $<0.000$ \\
H $(3, N=36)=22.65$ & & & \\
Total biomass of zooplankton & Jeziorzany 2 - Piekary & 3.315 & 0.006 \\
H $(3, N=36)=11.44$ & & & \\
Biomass of zooplankton feed on bacteria + algae & Jeziorzany1 - Tyniec & 2.707 & 0.041 \\
H $(3, N=36)=11.95$ & Piekary - Tyniec & 2.830 & 0.028 \\
Biomass of zooplankton feed on big algae & Jeziorzany 1 - Tyniec & 3.831 & $<0.000$ \\
H $(3, N=36)=14.96$ & & & \\
\hline
\end{tabular}


Table 4 Statistically significant Spearman correlations between various trophic groups of plankton occurring in the studied oxbow lakes $(p<0.05)$

\begin{tabular}{|c|c|c|}
\hline Biomass & Biomass & Coefficient \\
\hline \multirow[t]{3}{*}{ Phytoplankton in total } & $\begin{array}{l}\text { Herbivorous animals feed on small } \\
\quad \text { algae }(\text { dimension }<30 \mu \mathrm{m})\end{array}$ & -0.33 \\
\hline & $\begin{array}{l}\text { Herbivorous animals feed on big } \\
\quad \text { algae (dimension }>30 \mu \mathrm{m})\end{array}$ & 0.36 \\
\hline & Predator zooplankton & 0.49 \\
\hline Ciliates in total & Euglenoids & 0.33 \\
\hline \multirow[t]{2}{*}{ Zooplankton in total } & Golden brown algae & -0.33 \\
\hline & Algae- and bacterivorous ciliates & -0.63 \\
\hline Algivorous ciliates & Omnivorous ciliates & 0.78 \\
\hline \multirow[t]{3}{*}{ Algae- and bacterivorous ciliates } & Zooplankton in total & -0.63 \\
\hline & Predator zooplankton & -0.36 \\
\hline & Herbivorous animals feed on small algae & -0.47 \\
\hline \multirow[t]{4}{*}{ Omnivorous ciliates } & Algivorous ciliates & 0.78 \\
\hline & Herbivorous animals feed on small algae & 0.45 \\
\hline & Cryptomonads & 0.35 \\
\hline & Euglenoids & 0.41 \\
\hline Zooplankton feed on seston + bacteria & Herbivorous animals feed on big algae & -0.33 \\
\hline \multirow{6}{*}{$\begin{array}{l}\text { Herbivorous animals feed on algae } \\
\text { smaller dimension than } 30 \mu \mathrm{m}\end{array}$} & Phytoplankton in total & -0.34 \\
\hline & Algae- and bacterivorous ciliates & -0.47 \\
\hline & Omnivorous ciliates & 0.45 \\
\hline & Cyanobacteria & -0.33 \\
\hline & Dinoflagellates & -0.37 \\
\hline & Small green algae (dimension $<30 \mu \mathrm{m}$ ) & -0.45 \\
\hline \multirow{5}{*}{$\begin{array}{l}\text { Herbivorous animals feed on algae } \\
\text { bigger dimension than } 30 \mu \mathrm{m}\end{array}$} & Phytoplankton in total & 0.36 \\
\hline & Zooplankton feed on seston + bacteria & -0.34 \\
\hline & Predator zooplankton & 0.42 \\
\hline & Cyanobacteria & 0.43 \\
\hline & Euglenoids & 0.40 \\
\hline \multirow[t]{6}{*}{ Predator zooplankton } & Phytoplankton in total & 0.49 \\
\hline & Algae- and bacterivorous ciliates & -0.36 \\
\hline & Herbivorous animals feed on big algae & 0.42 \\
\hline & Cyanobacteria & 0.37 \\
\hline & Golden brown algae & -0.37 \\
\hline & Big green algae (dimension $>30 \mu \mathrm{m}$ ) & 0.51 \\
\hline \multirow[t]{2}{*}{ Cyanobacteria } & Golden brown algae & -0.35 \\
\hline & Dinoflagellates & 0.65 \\
\hline Dinoflagellates & Euglenoids & 0.47 \\
\hline
\end{tabular}

feeds on big algae (>30 $\mu \mathrm{m})$, conductivity, and oxygen concentration; (c) the biomass of euglenoids, the biomass of big diatoms, the biomass of dinoflagellates, and the biomass of golden brown algae; $(d)$ the biomass of cyanobacteria and cryptomonads, the biomass of small diatoms, the biomass of bacterivorous ciliates, the biomass of algivorous ciliates, the biomass of omnivorous ciliates, the biomass of zooplankton that feeds on the seston and bacteria, and the concentrations of $\mathrm{PO}_{4}{ }^{3-}, \mathrm{SO}_{4}{ }^{2-}, \mathrm{HCO}_{3}{ }^{-}$, and $\mathrm{Mg}^{2+} ;(e)$ the biomass of predator zooplankton was correlated with the $\mathrm{NO}_{3}{ }^{-}$concentration. Negative relationships were found between groups $a$ and $c$ and between groups $b$ and $d$.

\section{Discussion}

In the cascade model, the structure of the food web is determined by the trophic position of the component species: species in a higher trophic position can consume only species that occupy a lower position. The theoretical cascade model has been adopted in empirical studies, and now the trophic positions of species are commonly used to estimate food web structure and trophic connectivity [39]. Based on the biomass of various components of the plankton and the biomass of trophic groups, we constructed a model of the trophic network in small, shallow oxbow lakes. 


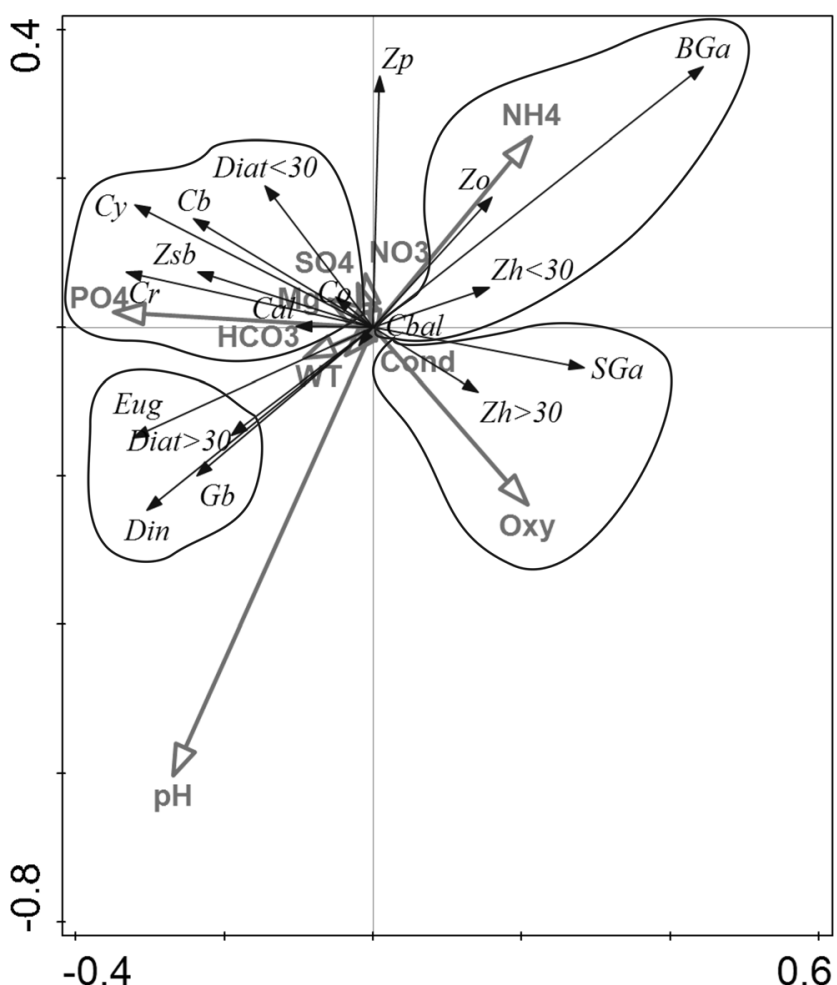

Fig. 5 Redundancy analysis (RDA) biplot of the relationships between trophic groups of plankton components and environmental factors (constrained partial analysis, partial RDA). Partial variation was 110.9344; the explanatory variables accounted for $42.3 \%$; adjusted explained variation was $1.1 \%$; eigenvalues: 0.0765 (axis 1); 0.0311 (axis 2), 0.0229 (axis 3), 0.0194 (axis 4); explained variation (cumulative): 17.54; $24.67 ; 29.92 ; 34.36$; pseudocanonical correlations: $0.8543 ; 0.7360$; $0.7225 ; 0.5692$; explained fitted variation (cumulative): 41.48; 58.33; 70.74; 81.24; permutation test results: on first axis, pseudo- $F=3.0, P=$ 0.186 ; on all axes, pseudo- $F=1.0, P=0.440$. Abbreviations: Din dinoflagellates, Eug euglenoids, $B G a$ big green algae, $S G a$ small green algae, $C y$ cyanobacteria, $G b$ golden brown algae, Diat $>30$ big diatoms, Diat $<$ 30 small diatoms, $\mathrm{Cr}$ cryptomonads. $\mathrm{Cal}$ algivorous ciliates, $\mathrm{Cbal}$ algivorous and bacterivorous ciliates, $\mathrm{Co}$ omnivorous ciliates, $\mathrm{Cb}$ bacterivorous ciliates. $Z p$ predator zooplankton, $Z o$ omnivorous zooplankton, $Z h<30$ herbivorous zooplankton that feeds on small algae, $Z h>30$ herbivorous zooplankton that feeds on big algae, Zsb zooplankton that feeds on the seston and bacteria

Phytoplankton forms the first trophic level that directly responds to changes in abiotic parameters [40]. Differences in physicochemical parameters such as conductivity and the concentrations of phosphates, nitrate nitrogen, and ammonia nitrogen resulted in clear differences in phytoplankton composition between the studied oxbow lakes. The differences at higher levels (e.g., ciliates, zooplankton) were not as conspicuous. We found differences in ciliate biomass and variability, but the dominance of trophic groups of ciliates was similar in the different oxbows, as the dominance of zooplankton trophic groups, which differed only for the zooplankton in the Tyniec oxbow (highest trophic status). There were significant differences in the biomass of trophic groups between the oxbows for some phytoplankton and zooplankton groups, but not for ciliates. It appears that ciliates are generalists, in that they can consume multiple resources [41]. Pelagic ciliates are the main component of the microzooplankton, forming up to $34 \%$ of the total zooplankton biomass in eutrophic lakes and up to $62 \%$ of it in hypertrophic lakes [42, 43]. In our study, the share of plankton ciliates in total zooplankton biomass ranged from $6.7 \%$ in Jeziorzany 1 to $44.5 \%$ in the Piekary oxbow.

In redundancy analysis, physicochemical factors explained $42.3 \%$ of the variability in the trophic groups of plankton. Simple correlations allowed us to delineate trophic network connectivity among the plankton organisms, implying direct and indirect relationships such as competition, predation, coexistence, disturbance, and resource heterogeneity (Fig. 6a-c and 7). Predation was shown by a negative correlation between total phytoplankton biomass and the biomass of herbivorous zooplankton that feeds on small algae $(<30 \mu \mathrm{m})$. An indirect relationship was seen between total phytoplankton biomass and the biomass of predator zooplankton; the positive correlation suggests an undisclosed link (herbivorous animals) between phytoplankton and predators. The positive correlation between total phytoplankton biomass and the biomass of zooplankton that feeds on big algae $(>30 \mu \mathrm{m})$ indicates that an increase in zooplankton that feeds on big algae promotes an increase in the total biomass of phytoplankton, and vice versa.

The positive correlation between the total biomass of ciliates and that of euglenoids (Figs. $6 \mathrm{~b}$ and 7) is explained by their coexistence or by their food resource heterogeneity (heterotrophy and autotrophy). Moreover, both groups are mobile and can seek food by moving in the water.

The negative correlation between total zooplankton biomass and the biomass of ciliates that feed on algae + bacteria (Figs. 6c and 7) showed a direct relationship reflecting predation of plankton animals on ciliates. Field and laboratory experiments have shown that the impact of grazing on the ciliate stock by copepods is greatest when the phytoplankton concentration is low and when it is dominated by small phytoflagellates [44].

The negative correlation between zooplankton biomass and the biomass of golden brown algae is unclear and difficult to explain.

We found a number of more specific relationships between particular trophic groups of plankton (Fig. 7). Different phytoplankton groups were related to each other: cyanobacteria to dinoflagellates, and dinoflagellates to euglenoids. There were other relationships between phytoplankton groups and different trophic groups of zooplankton. Only euglenoids and cryptomonads were correlated with omnivorous ciliates. In general, phytoplankton groups showed more connections with different zooplankton groups and among themselves, but ciliate groups showed more connections among themselves and with zooplankton groups. These simple relationships support the notion that ciliates transfer organic matter to zooplankton. According to the microbial loop concept, the dissolved 
a

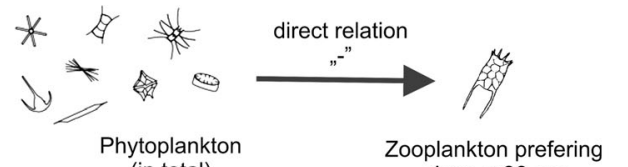

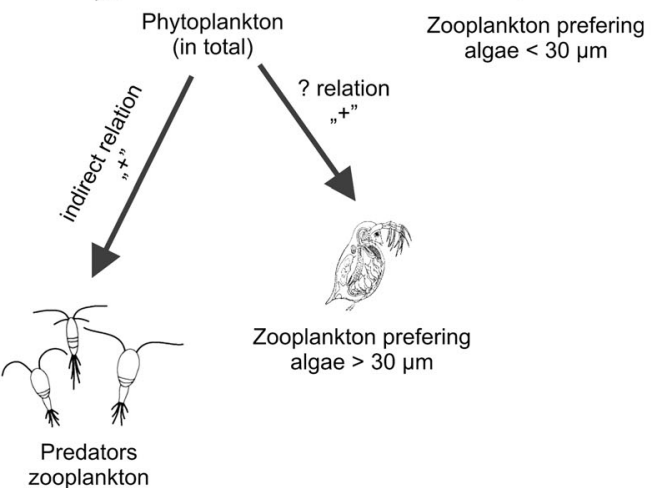

b

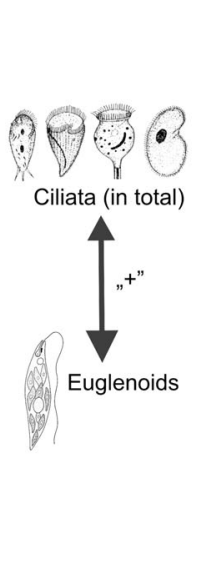

C
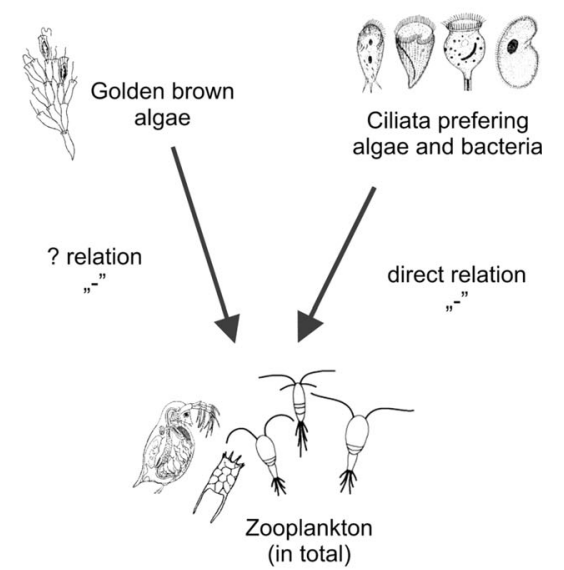

Fig. 6 Model of the relationships between the plankton in oxbow lakes (only significant ones shown): a total biomass of phytoplankton; b total biomass of ciliates; and $\mathbf{c}$ total biomass of zooplankton

organic carbon released by phytoplankton is used by bacteria, which are then preyed upon by protozoa that are subsequently consumed by zooplankton $[45,46]$.

The simple positive correlation observed between the biomass of cyanobacteria and dinoflagellates is supported by laboratory experiments demonstrating allelopathic interactions between dinoflagellates and toxic cyanobacteria [47]. Simple positive relationships between dinoflagellates and euglenoids might be explained as coexistence. We speculate that because both of these organisms are mobile

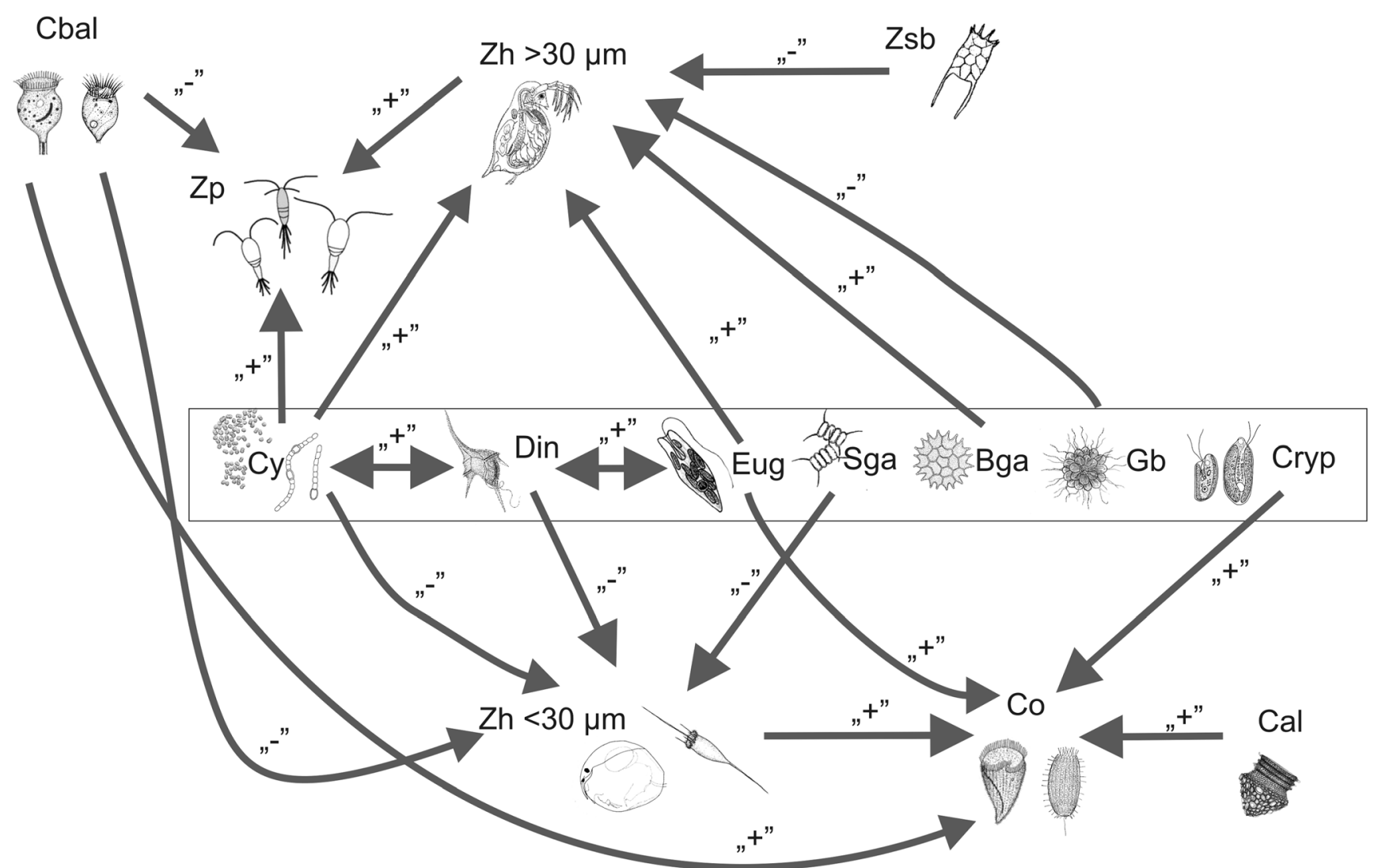

Fig. 7 Model of the trophic network among plankton components in small shallow oxbow lakes. Abbreviations: Din dinoflagellates, Eug euglenoids, $B G a$ big green algae, $S G a$ small green, $C y$ cyanobacteria, $\mathrm{Gb}$ golden brown algae, $\mathrm{Cr}$ cryptomonads. $\mathrm{Cal}$ algivorous ciliates, $\mathrm{Cbal}$ algivorous and bacterivorous ciliates, $C o$ omnivorous ciliates. $Z p$ predator zooplankton, $Z h<30 \mu m$ herbivorous zooplankton that feeds on small algae, $Z h>30 \mu m$ herbivorous zooplankton that feeds on big algae, $Z s b$ zooplankton that feeds on the seston and bacteria; "-" negative relation, "+" positive relation 
and mixotrophic, they can use alternative methods of feeding and do not compete.

The negative correlation between the biomass of herbivorous zooplankton that feeds on small algae and the biomass of small green algae $(<30 \mu \mathrm{m})$ are explained by grazing, and the negative correlation between the biomass of herbivorous zooplankton and that of ciliates that feed on bacteria and algae can be explained by competition.

Many studies have suggested that the biomass of some herbivorous zooplankton species (mostly Daphnia species) decreases during cyanobacterial blooms [48]. Often a negative correlation between the biomass of herbivorous zooplankton and that of dinoflagellates and cyanobacteria is explained as a lack of a food source for zooplankton. This would seem to make the positive relationships we found between these organisms and cyanobacterial biomass difficult to explain. However, recent reports increasingly suggest that Daphniacyanobacteria relationships are more complicated than previously thought and that a decrease in the daphnid population during cyanobacterial blooms is not necessarily the result of toxins [49]. Moreover, short-term exposure to toxic cyanobacteria can improve the fitness of Daphnia magna for further exposure to toxic prey during development. This trait might be transferred to offspring via maternal effects, or such an adaptation might be clone-specific [50].

The negative correlation between the biomass of herbivorous zooplankton species that feed on big algae $(>30 \mu \mathrm{m})$ and that of zooplankton species that feed on the seston and bacteria may suggest some unknown type of competition. Animals that feed on the seston and bacteria are an important link in the transfer of carbon from bacterial biomass to macrozooplankton [51, 52], and might compete with ciliates which also transfer organic matter from bacteria in a microbial loop. This possibility will be the focus of our future work.

Predation may also explain the negative relationship between the biomass of predator zooplankton and the biomass of ciliates that feed on bacteria and algae. Copepods, which traditionally have been considered to be herbivores, are in fact omnivores which also feed on heterotrophic protists and are inefficient at feeding on prey less than $5-10 \mu \mathrm{m}$ in size [53]. Large-bodied copepods can effectively consume protists (heterotrophic nanoflagellates and ciliates), rotifers, and cladocerans [54].

Simple relationships allowed us to outline the trophic network among plankton components in the four small shallow oxbow lakes we studied. The network was underpinned by adding plankton ciliates, which are often neglected in such studies. In general, the relationships indicated the flow of organic matter from phytoplankton to zooplankton and from ciliates to zooplankton.
Acknowledgments We thank the anonymous reviewers for their helpful comments and suggestions and $\mathrm{PhD}$ Piotr Skórka for discussion on statistics. This work was supported by the Institute of Nature Conservation, Polish Academy of Sciences (Kraków, Poland) through grant funding for $\mathrm{PhD}$ students and young scientists and through the Institute's statutory funds. The authors are grateful to Michael Jacobs for editing of the manuscript.

Open Access This article is distributed under the terms of the Creative Commons Attribution 4.0 International License (http:// creativecommons.org/licenses/by/4.0/), which permits unrestricted use, distribution, and reproduction in any medium, provided you give appropriate credit to the original author(s) and the source, provide a link to the Creative Commons license, and indicate if changes were made.

\section{References}

1. Heintz MD, Hagemeier-Klose M, Wagner K (2012) Towards a risk governance culture in flood policy-findings from the implementation of the "Floods Directive" in Germany. Water 4(1):135-156

2. Obolewski K, Glińska-Lewczuk K (2011) Effect of oxbow reconnection based on the distribution and structure of benthic macroinvertebrates clean. Soil Air Water 39:853

3. Gadzinowska J (2013) Plankton communities in oxbow lakes of the River Vistula (Oświęcim Basin) with bottom sediments heterogeneously contaminated with heavy metals. Limnol Review 13(2): 93-104

4. Schindler S, Sebesvari Z, Damm C, Euller K, Mauerhofer V, Schneidergruber A et al (2014) Multifunctionality of floodplain landscapes: relating management options to ecosystem services. Landscape ecol 29(2):229-244

5. Pomeroy LR (1974) The ocean's food web, a changing paradigm. BioScience 24:499-504

6. Porter KG, Pace ML, Battey JF (1979) Ciliate protozoans as links in freshwater planktonic food chains. Nature 277:563-565

7. Arndt H (1993) Rotifers as predators on components of microbial web (bacteria, heterotrophic flagellates, ciliates). Hydrobiologia 255/256:231-246

8. Gilbert JJ, Jack JD (1993) Rotifers as predators on small ciliates. Hydrobiologia 255/256: 247-253

9. Chróst RJ, Adamczewski T, Kalinowska K, Skowrońska A (2009) Abundance and structure of microbial loop components (bacteria and protists) in lakes of different trophic status. J Microbiol Biotechnol 19(9):858-868

10. Archbold JHG, Berger J (1985) A qualitative assessment of some metazoan predators of Halteria gradinella, a common freshwater ciliate. Hydrobiologia 126:97-102

11. Porter KG, Pearl H, Hodson R, Pace ML, Priscu J, Riemann B, Scavia D, Stockner JG (1988) Microbial interactions in lake food webs. In: Carpenter SR (ed) Complex interactions in lake communities

12. Weisse T, Müller H, Pinto-Coelho RM, Schweizer A, Sprigmann D, Baldringer G (1990) Response of the microbial loop to the phytoplankton spring bloom in a large prealpine lake. Limnol Oceanogr 35:781-794

13. Christofersen K, Riemann B, Hansen LR, Klysner A, Sorensen HB (1990) Qualitative importance of the microbial loop and plankton community structure in a eutrophic lake during a bloom of cyanobacteria. Microb Ecol 20:253-272

14. Sommer U, Gliwicz ZM, Lampert W, Duncan A (1986) The PEGmodel of seasonal succession of planktonic events in fresh waters. Arch Hydrobiol 106(4):433-471 
15. Glińska-Lewczuk K, Burandt P (2011) Effect of river straightening on the hydrochemical properties of floodplain lakes: observations from the Eyna and Drwęca Rivers, N Poland. Ecol Eng 37(5):786795

16. Grabowska M, Glińska-Lewczuk K, Obolewski K, Burandt P, Kobus S, Dunalska J, Kujawa R, Goździejewska A, Skrzypczak A (2014) Effects of hydrological and physicochemical factors on phytoplankton communities in floodplain lakes. Pol J Environ Stud 23(3):713-725

17. Segovia BT, Pereira DG, Bini LM, de Meira BR, Nishida VS, Lansac-Tôha FA, Velho LFM (2015) The role of microorganisms in a planktonic food web of a floodplain lake. Microb Ecol 69(2): 225-233

18. Taylor WD, Heynen ML (1987) Seasonal and vertical distribution of ciliaphora in lake Ontario. Can J Fish Aquat Sci 44:2185-2191

19. Amblard C, Carrias JF, Bourdier G, Maurin N (1995) The microbial loop in a humic lake: seasonal and vertical variations in the structure of different communities. Hydrobiologia 300(301):71-84

20. Shapiro J, Lamarra VA, Lynch M (1975) Biomanipulation: an ecosystem approach to lake restoration. In: Brezonik PL, Fox JL (eds) Proceedings of a symposium on water quality management through biological control. Univ. of Florida, Gainesville, pp 85-96

21. Rott E (1981) Some results from phytoplankton counting intercalibrations. Schweiz Z Hydrol 43:34-62

22. Foissner W, Berger H (1996) A user-friendly guide to the ciliates (Protozoa, Ciliophora) commonly used by hydrobiologists as bioindicators in rivers, lakes, and waste waters, with notes on their ecology. Freshwater Biol 35(2):375-482

23. Foissner W, Berger H, Schaumburg J (1999) Identification and ecology of limnetic plankton ciliates. Informationsberichte des Bayer. Landesamtes für Wasserwirtschaft, München

24. Jerome CA, Montagnes DJS, Taylor FJR (1993) The effect of the quantitative protargol stain and Lugols and Buinos fixatives on cell size: a more accurate estimate of ciliate species biomass. J Euk Microbiol 40:254-259

25. Menden-Deuer S, Lessard EJ (2000) Carbon to volume relationships for dinoflagellates, diatoms, and other protist plankton. Limnol Oceanogr 45:569-579

26. Wiąckowski K, Doniec A, Fyda J (1994) An empirical study of the effect of fixation on ciliate cell volume. Mar Microb Food Webs 8(1-2):59-69

27. Putt M, Stoecker DK (1989) An experimentally determined carbon: volume ratio for marine "oligotrichous" ciliates from estuarine and coastal waters. Limnol Oceanogr 34:1097-1103

28. Dussart B (1967) Les Copépodes des eaux contonentals d'Europe occidentale: Calanoides et harpacticopides. Boubée \& Cie, Paris

29. Dussart B (1969) Les Copépodes des eaux continentals d'Europe occidentale: Cyclopoides et biologie. Boubée \& Cie, Paris

30. Flößner D (2000) Die Haplopoda und Cladocera (Ohne Bosminidae) Mitteleuropas. Backhuys, Leiden

31. Ejsmont-Karabin J, Radwan S, Bielańska-Grajner I (2004) Rotifers. Monogononta - atlas of species. Polish Freshwater Fauna. University of Łódź, Łódź, pp 77-447 [in Polish]

32. Cummins KW, Costa RR, Rowe RE, Moshiri GA, Scanlon RM, Zajdel RK (1969) Ecological energetics of a natural population of the predaceous zooplankter Leptodora kindtii. Oikos 20:189-223

33. Dumont HJ, Van de Velde I, Dumont S (1975) The dry weight estimate of biomass in a selection of Cladocera, Copepoda and Rotifera from the plankton, periphyton, and benthos of continental waters. Oecol (Berl) 19:75-97

34. Bottrell HH, Duncan A, Gliwicz ZM, Grygierek E, Herzig A, Hillbricht-Ilkowska A, Kurasawa H, Larsson P, Weglenska T (1976) A review of some problems in zooplankton production studies. Norw J Zool 24:419-456
35. Ruttner-Kolisko A (1977) Suggestions for biomass calculation of plankton rotifers. Arch Hydrobiol Beih Ergebn Limnol 8(7):1-76

36. Pearsson G, Ekbohm G (1980) Estimation of dry-weight in zooplankton populations - methods applied to crustacean populations from lakes in the Kuokkel Area, Northern Sweden. Arch Hydrobiol $89: 225-246$

37. Sanders RW, Porter KG, Caron DA (1990) Relationship between phototrophy and phagotrophy in the mixotrophic chrysophyte Poterioochromonas malhamensis. Microb Ecol 19(1):97-109

38. Wilk-Woźniak E, Pociecha A, Bucka H (2001) Phytoplanktonzooplankton interactions, size relations and adaptive responses. A short review. Ecohydrol Hydrobiol 1(4):511-517

39. Boyce DG, Frank KT, Leggett WC (2015) From mice to elephants: overturning the 'one size fits all'paradigm in marine plankton food chains. Ecol Lett 18(6):504-515

40. Dunson WA, Travis J (1991) The role of abiotic factors in community organization. Am Nat 138:1067-1091

41. MacArthur RH (1972) Geographical ecology: patterns in the distribution of species. Princeton Univ. Press

42. Pace M, Orcutt JD Jr (1981) The relative importance of protozoans, rotifers and crustaceans in a freshwater zooplankton community. Limnol Oceanogr 26:822-830

43. Beaver JR, Crisman TL (1990) Seasonality of planktonic ciliated protozoa in 20 subtropical Florida lakes of varying trophic state. Hydrobiologia 190:127-135

44. Jakobsen HH, Hansen P (1997) Prey size selection, grazing and growth response of the small heterotrophic dinoflagellate Gymnodinium sp. and the ciliate Balanion comatum-a comparative study. Mar ecol-prog ser 158:75-86

45. Sherr EB, Sherr BF (1988) Role of microbes in pelagic food webs: a revised concept. Limnol Oceanogr 33:1225-1227

46. Kalinowska K (2004) Bacteria, nanoflagellates and ciliates as components of the microbial loop in three lakes of different trophic status. Pol J Ecol 52(1):19-34

47. Vardi A, Schatz D, Beeri K, Motro U, Sukenik A, Levine A, Kaplan A (2002) Dinoflagellate-cyanobacterium communication may determine the composition of phytoplankton assemblage in a mesotrophic lake. Curr Biol 12(20):1767-1772

48. Hietala J, Laurén-Määttä C, Walls M (1996) Sensitivity of Daphnia to toxic cyanobacteria: effects of genotype and temperature. Freshwater Biol 37:299-306

49. Wojtal-Frankiewicz A, Kruk A, Frankiewicz P, Oleksińska Z, Izydorczyk K (2015) Long-term patterns in the population dynamics of Daphnia longispina, Leptodora kindtii and cyanobacteria in a shallow reservoir: a self-organising Map (SOM) approach. PLoS One 10(12):e0144109

50. Lyu K, Guan H, Wu C, Wang X, Wilson AE, Yang Z (2015) Maternal consumption of non-toxic Microcystis by Daphnia magna induces tolerance to toxic Microcystis in offspring. Freshwater Biol, DOI:10.1111/fwb.12695

51. Stockner JG, Shortreed KS (1989) Algal picoplankton and contribution to food webs in oligotrophic British Columbia Lakes. Hydrobiologia 173:151-166

52. Wilk-Woźniak E, Pociecha A, Amirowicz A, Gąsiorowski M, Gadzinowska J (2014) Do planktonic rotifers rely on terrestrial organic matter as a food source in reservoir ecosystems? Int Rev Hydrobiol 99(1-2):157-160

53. Löder MG, Meunier C, Wiltshire KH, Boersma M, Aberle N (2011) The role of ciliates, heterotrophic dinoflagellates and copepods in structuring spring plankton communities at Helgoland Roads, North Sea. Mar Biol 158(7):1551-1580

54. Kalinowska K, Ejsmont-Karabin J, Rzepecki M, KostrzewskaSzlakowska I, Feniova IY, Palash A, Dzialowski AR (2015) Impacts of large-bodied crustaceans on the microbial loop. Hydrobiologia 744(1):115-125 